\title{
PUBLIC SPACE REGENERATION STRATEGIES: THE CASE OF SALOU
}

\author{
N. SALVADO ${ }^{1}$, I. DE RIVERA ${ }^{2} \&$ D. LORENZO ${ }^{2}$ \\ ${ }^{1}$ Departamento de Proyectos Arquitectónicos de la UPC, Spain. \\ ${ }^{2}$ Unidad Predepartamental de Arquitectura, URV, Spain.
}

\begin{abstract}
Salou, which is one of the many highly specialized tourist resorts located on the Spanish Mediterranean coast, is a hundred kilometres south of Barcelona. Within its narrow boundaries of 1.481 ha, Salou hosts 7.4 million overnight stays per year and is home to 52 hotels. A ratio which ranks Salou amongst the tenth most visited municipalities in Spain [1].

Distance from Salou's historical town centre, the area of Carles Buigas Avenue (CB) emerges as being the heart of the municipality's tourism and leisure industry. Salou developed, as did so many other Spanish coastal touristic locations, during the sixties and seventies as a consequence of the increasing demand for sun and beach destinations amongst the European and Spanish middle classes. Unfortunately, the "ageing" of this built up area clamours for close attention today. The visible physical degradation of the property is becoming a cause for concern and preoccupation amongst the main property owners and investors: public administration, hotel managers, shopkeepers and neighbours.

Hotels emerge as the key problem within the set physical boundaries of this study. They occupy approximately $50 \%$ of the total land surface, 28 out of a total of 52 hotels within the town being concentrated in that area. This accumulation of hotels also breaks the particularity of the predominance of second residences which is so customary along the Spanish Coast.

This paper delves into the data and proposals obtained from analysing the public space of the $\mathrm{CB}$ area. Similarly, as a consequence of the previous analysis, a set of proposals for intervention are also presented. The proposals are conceived to be developed within different time scales, in response to political and social willingness and economic capacity. The objective of the work is to induce an urban and tourism paradigm shift in the area, thus facilitating the emergence of a new tourism model. Solutions are urgently needed to provide specific answers to a particular scenario, which has similitudes to those of other Mediterranean Coastal Developments specialized in tourism activities, which too, after being operative for more than forty years, are suffering from deterioration or abandonment.

Despite it still being an open process, the study understands that due to the complexity of the committed task and the scale of the area, the goal will require the active commitment and collaboration of the property owners (administration, hotel managers, investors and neighbours).

Keywords: coastal planning, coastal tourism, ecology, public space quality, sustainable development, tourism specialization, urban decay, urban design urban regeneration, urban strategy.
\end{abstract}

\section{INTRODUCTION}

The Mediterranean coastal town of Salou is located $100 \mathrm{~km}$ south of Barcelona in the geographical locality of Camp de Tarragona, An area with a GDP growth 3 points over the Catalunya average between 2001-2005 [2]. Camp de Tarragona itself is a complex area, in which towns, tourism and industry have coexisted in a very intense and possibly contradictory manner since the last century.

Salou is the main town of the Mediterranean coastal tourist destination known as "Costa Dorada" (Fig. 1). The town grew around its commercial port, which was very important up until the late nineteenth century, from which it developed into a summer and tourist resort in the early twentieth century, thanks to the railway connection linking it to Reus. The train popularly called the "carrilet" transported bathers and holidaymakers to the beaches of "Poniente" and "Levante" (Figs 1 and 2), two of the largest coastal beaches located in the flat area of the municipality of Salou. 


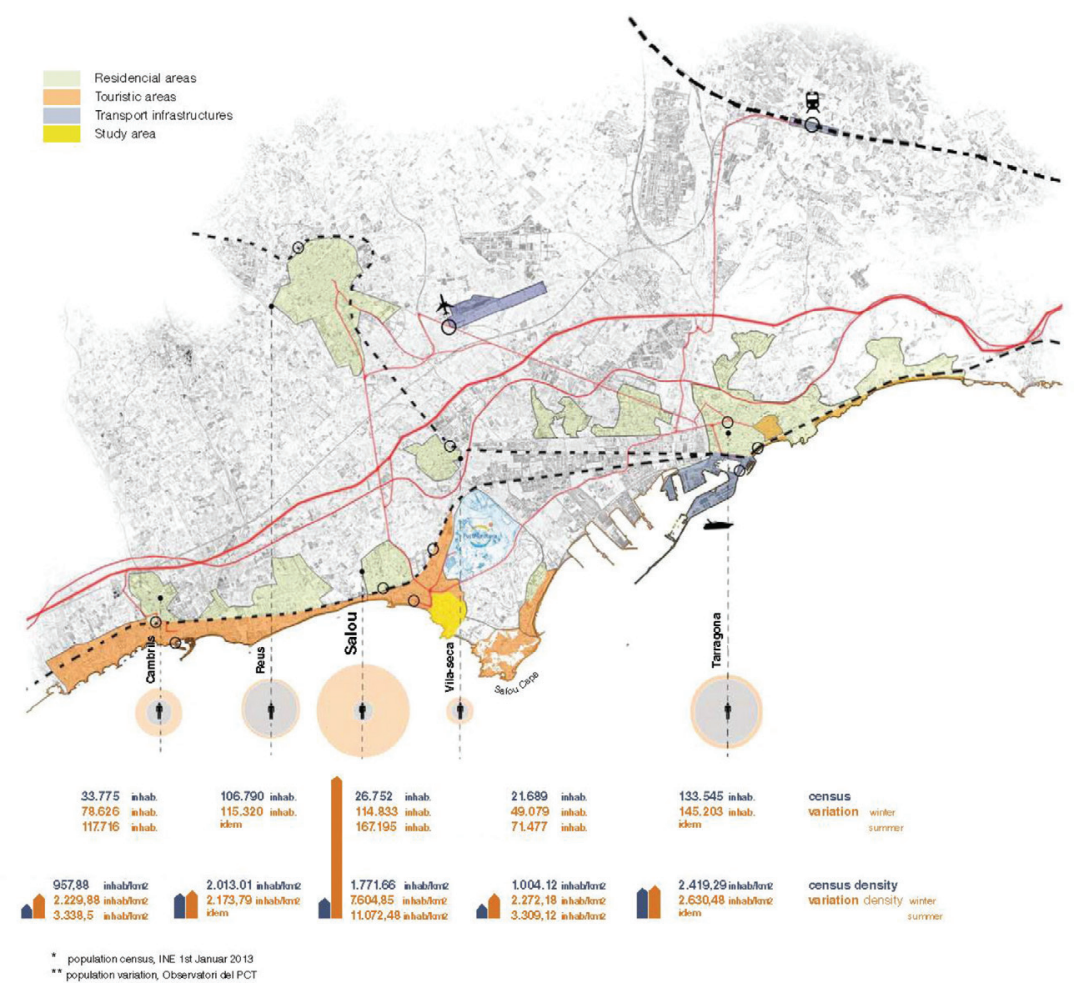

Figure 1: The "Costa Dorada" context.

The tourist developments along the Mediterranean coast are of a seasonal nature [3]. Salou's population growth is linked to tourism; it has high variations between seasons [4]. In the summer months the population increases by six, which defines the rhythm of economic activity [5].

Salou is a benchmark for tourism on the Catalan coast, and was placed in the tenth position with respect to the number of overnight stays in Spain 2013 [6]. The municipality has a total of 69 tourist establishments and 3 campsites, providing a total of 30,000 to 37,000 hotel places (beds) [7, 8]. Its economic activity is concentrated in the months of July and August, although there is a growing tendency towards extending the season. However, at present, there is no activity whatsoever in the hotel sector between the second fortnight of November and the beginning of the second half of February, coinciding with the temporary closure of the Port Aventura theme park.

The urban development has been polarized during the development of the town. Whilst the oldest hotel structures (developed during the 60's and the 70's) are concentrated at one end of the town around the Carles Buigas (CB) Avenue, the newest ones are concentrated around the theme park (Port Aventura), and the urban facilities are located at the other end of the town in the area known as Barcelona Street.

After forty years, the area requires a thorough revision due to evidence of urban degradation. The initial analysis has been focused on three main areas: common space, hotel facilities, and commercial and leisure activities. The results have shown a lack of public and private investment within the area, and a risk of obsolescence of the urban and tourism model. The hotel facilities have not been refurbished or renovated since their initial development, apart 


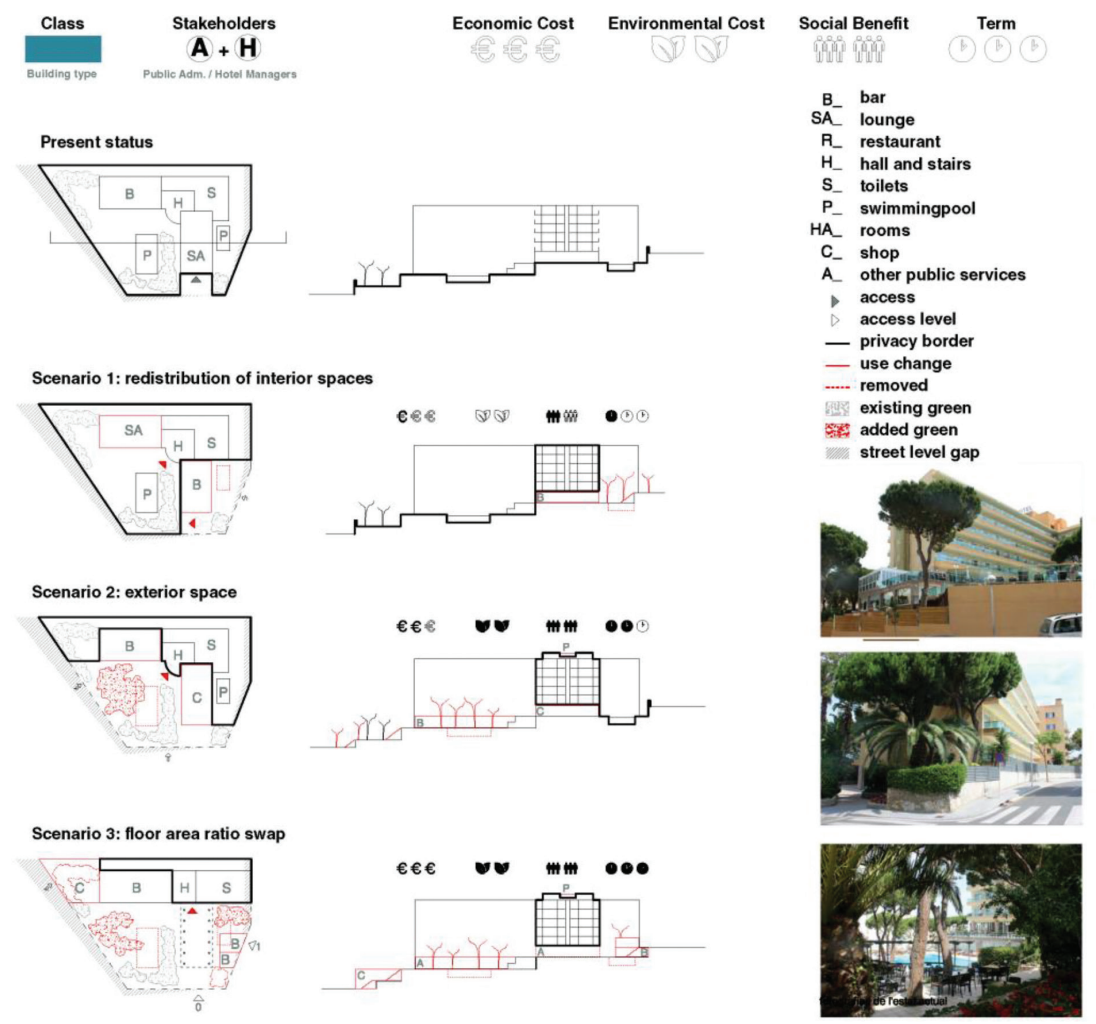

Figure 2: Hotels renovation and opening.

from essential maintenance work. Moreover, the commercial activities have grown out of control as a result of an increasing demand for specialized leisure and night activities.

Over a period of four months, from January to April 2014, graphic and statistical documents have been undertaken to identify the logic and organization behind the area of study [9]. The analysis considers three aspects: the physical constraints of the site, the urban constraints and the economic and use constraints.

Drawing out the area's existing urban developments was our main analytical method, it was necessarily the starting point of our efforts to learn about the site [10]. Understanding how the city functions in real life is essential for the creation of a consistent strategy to improve social and economic life [11].

After this analysis the team focused on developing a diagnosis that would allow the development of specific proposals in an environment capable of regenerating and reversing the current degradation tendency. In this article we present those problems affecting public administration and which directly affect the quality of public space, design and planning.

\section{AREA OF STUDY}

\subsection{Main data}

The area of study is located in the South-East of the town of Salou, and its backbone is the Carles Buigas (CB) Avenue. This road has a great deal of commercial activity, and 
the area acts as the link between the town centre and the Passeig de Jaume I: the town's historic waterfront and major tourism and commercial hub. The area of study covered is $768,082 \mathrm{~m}^{2}$.

It is an urban area, consisting mainly of detached buildings mostly used for hotels and apartment-hotels, although there are some small isolated summer houses and apartment blocks used as second residences.

The area we are analysing has the particularity of being the point where the topographic coastal relief begins that configures Salou Cape, another touristic area of Salou, which boarders the Pineda (Vila-seca). Within its limits one can clearly define two specific zones that are delimited by Carles Buigas Avenue: that of the northern zone with much larger plots and topographically a lot flatter (only the Park of Salou presents a slope and a limit between its own plot of land and the surrounding streets); and the southern zone, which borders the Sea and whose topographical relief is formed by cliffs and small bays: The cove of the beach of "Capellans" and the inlet of the "Llenguadets". The first centred within the area and the other located on its extreme.

It is therefore in this area, delimited between Carles Buigas Avenue and the Sea, where the plots of land have to topographically resolve their relationship with the street, where one can discover conflictive points of contact between the built up space and the natural relief of the land. While the smaller plots with isolated buildings dedicated to housing have a more friendly relationship with the street and the topography, in contrast the hotel plots that have a much greater dimension present large walls or barriers that separate the public space from the private (Fig. 3). This difference is a consequence of the need to generate a large flat surface area to locate the hotel's pool and recreation area.

In the plan, Fig. 4, by means of drawing the boundaries and topographical changes one can recognize and differentiate the plots that are more than a meter above street level (dark green) and those that are sunken below the public space level (light green), giving us a clear idea of the walls and vertical cuts caused by this cross between topography and use.

\subsection{Mobility}

The neighbourhood is connected to the town of Salou, to Reus and Tarragona through three main axis: Carles Buigas Avenue, Principat d'Andorra Avenue and Pompeu Fabra Avenue. Although Brussel-les Street was the main connection between Salou Cape and the Coast Road in the past, it has lost its importance nowadays due to its continuity being cut off by the tourist resort Lumine, which acts as a barrier between the urban area of Salou and Salou Cape. However, it still maintains its importance as an inter-municipal connector. An example of this is the public transport line that connects them in this part of town: the line CambrilsSalou-Salou Cape-Tarragona, which provides service to residents and visitors nearby. The other streets give an internal service.
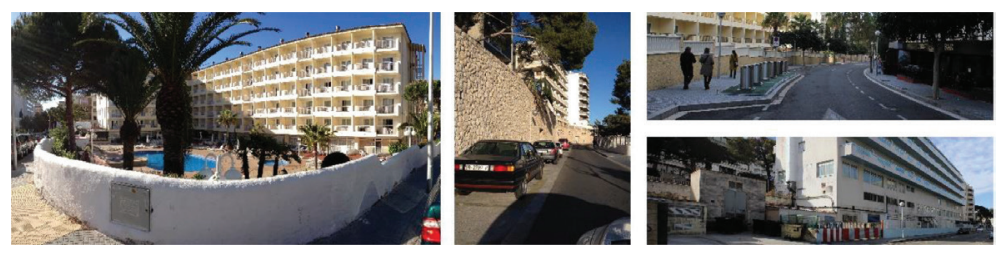

Figure 3: Street walls along the property plots in Salou. 


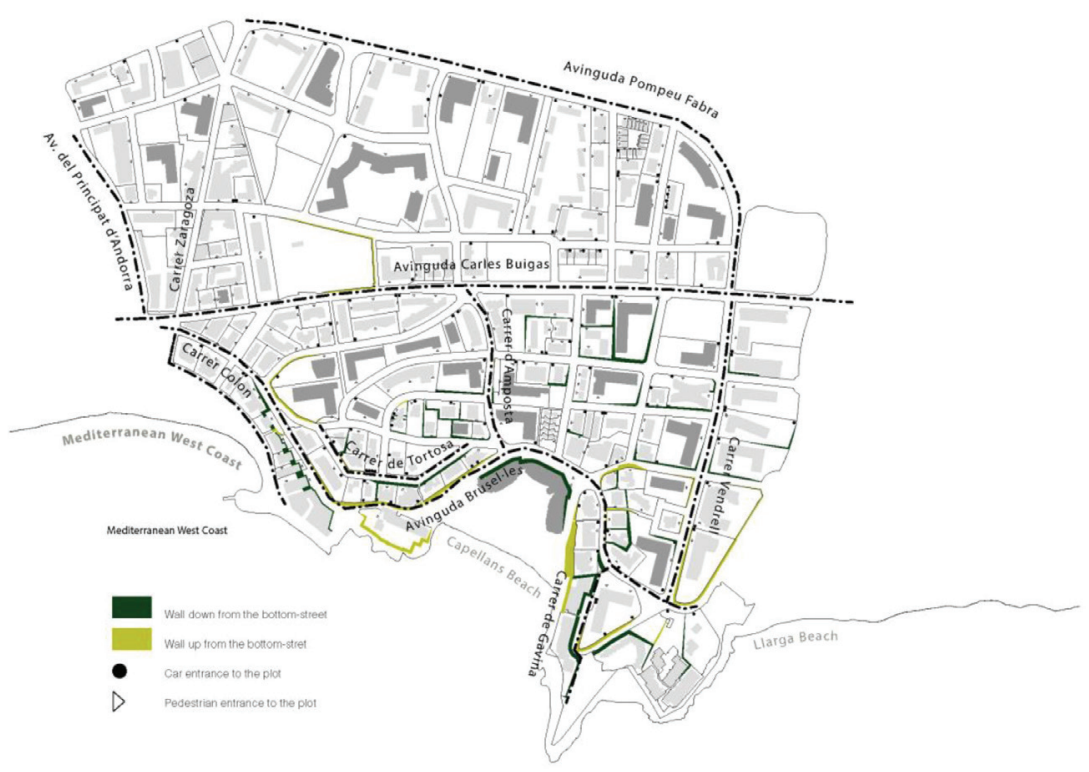

Figure 4: Modifications of the topography of the site.

Carles Buigas Avenue, which provides commercial continuity to Passeig Jaume I, is undoubtedly the backbone of the whole area and requires special attention in this study. The other roads that also have more pedestrian intensity are: the continuation of Colon Street via the coast with the new "Seaside Path" that leads to Llarga beach, and the streets of Amposta and Valls that connect the area to the beach of Capellans.

Other data to consider is the large amount of public land designated to roads and parking. Of a total area of public domain comprising 22,3 Ha (which includes streets, pavements, pedestrian zones, parks and gardens), the area designated to roads is $92.198,3 \mathrm{~m} 2(41.24 \%)$ and the public parking area represents $11,68 \%\left(26.164 \mathrm{~m}^{2}\right)$, some 2090 places, while the private parking area represents 3,94\% of the entire study area, some 330 places (Fig. 5).

The high number of free parking spaces available on the street has the effect of making alternative payment parking, whether municipal or that offered by hotels in the area, most of the time under-used (Fig. 6).

\subsection{Public Space}

The area in the public domain accounts for $30 \%$ of the study area $\left(223.579,4 \mathrm{~m}^{2}\right)$, of which only $38.41 \%$ is guaranteed space for pedestrians 24 hours a day (pavements and pedestrian streets), $20.35 \%$ is occupied by parks and gardens with restricted opening hours, and the remaining $41.24 \%$ is allocated to vehicles.

Concerning this $30 \%$ of the public domain, the pedestrian-vehicles hierarchy is unclear, the space exclusively dedicated to pedestrians not being very fluid or continuous. In an area that receives 11,000 visitors in its moments of maximum stress, there are few streets exclusively for pedestrians. Only Zaragoza Street, which has a commercial character, and the "Seaside Path", which is a promenade in front of the sea that gives continuity to the promenade of the Llarga beach are the sample of public pedestrian space and easily accessible. 


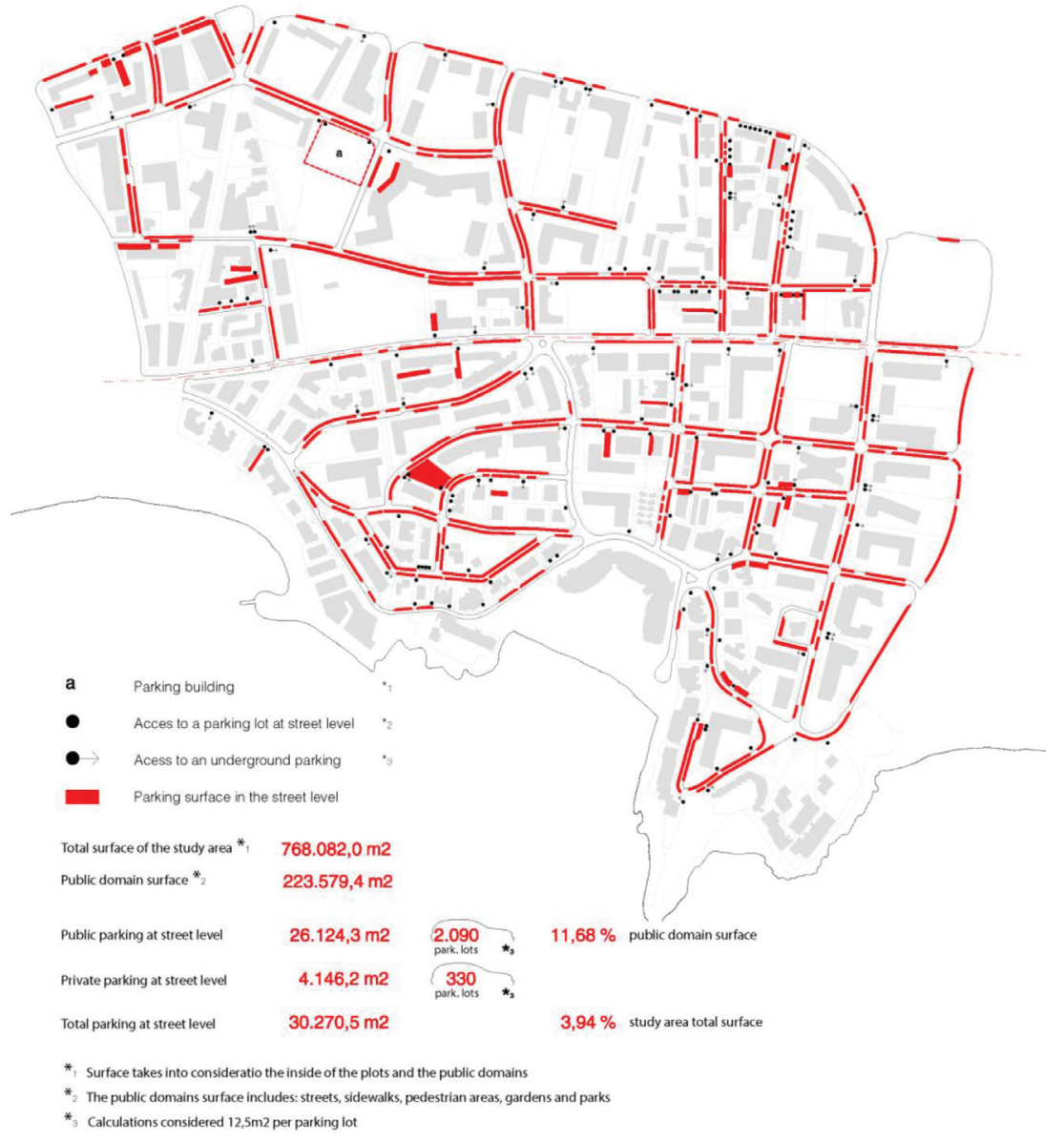

Figure 5: Parking areas.
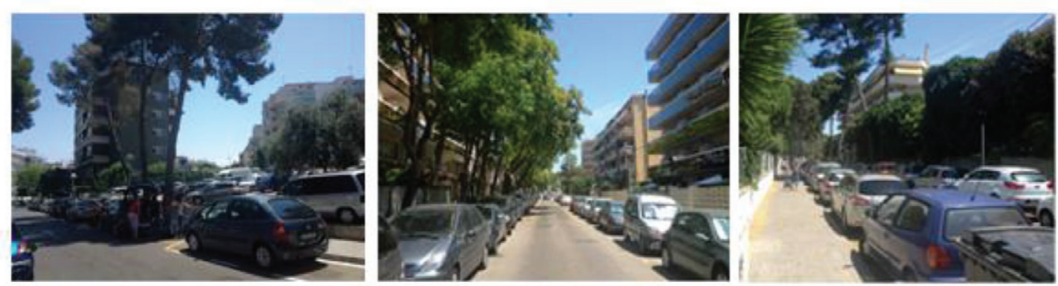

Parking in summer season
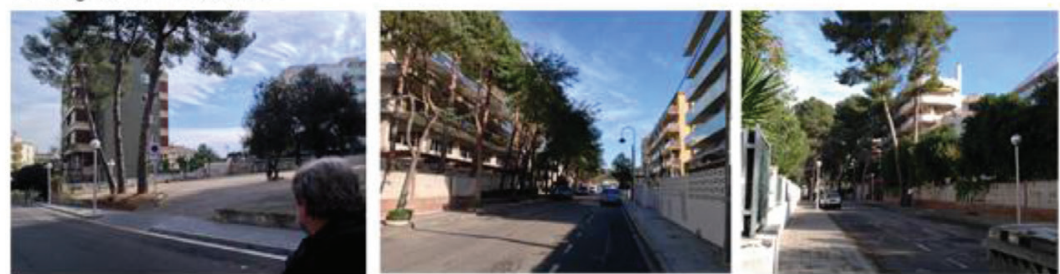

Parking in winter season

Figure 6: Summer - winter parking. 
If we pay attention to the quality of the pedestrian space within the field of study, we realize that the topographic factor and the orientation of the plots clearly aggravate the pedestrian permeability of the southern sector. As previously mentioned, the steep topography has given place to major platforms that level the plots, resulting in a hermetic and impassable limit, and the quality impoverishment of streets and public spaces.

The buildings located between Brussel- les Street and Tortosa Street, as well as those located between Brussel-les Street and Gavina Street create an impassable wall or barrier for pedestrians, which is only surpassed by the views and its relation with the Sea. In other streets, without the added value of visual contact with the Sea, the quality of public space is even lower (Fig. 4).

The study of the types of trees within this area has allowed us to differentiate between deciduous and evergreen, the height and the density of shadow, establishing the level of comfort of the streets in the summer. It was considered that streets with dense vegetation were in no doubt the streets most desired for pedestrian routes.

Observing Fig. 7, we can establish that the presence of trees is concentrated mainly on the Carles Buigas Avenue in the northern sector of the area, with evergreen trees of a certain height. In the southern sector the trees are only concentrated on the main streets - Brussel-les Street, Amposta Street and Vendrell Street - with smaller deciduous trees on Vendrell Street and palm trees on Colon Street.

The pavement width of most of the streets is less than $2 \mathrm{~m}$, except the East-West longitudinal axis and two of the North-South transversal routes, Amposta and Vendrell Streets, coinciding with tree areas.

\section{SPECIFIC PROPOSALS TO GET RID OF THE DEGRADATION PROCESS IN PUBLIC SPACE}

On the basis of all the analysis developed over more than a year and synthesized in the previous points, the following conclusions are obtained:

\subsection{Streets and the quality of public space}

1. The perimeter condition of Brussel- les Street, the Coastal Road and Pompeu Fabra Avenue allow placing a ring-road access, emptying the traffic within the centre of the area and establishing a hierarchy between streets, pacifying the area and correctly dimensioning the pavements and roads, giving priority to pedestrians and eliminating the unevenness between the road and sidewalk.

The scenario posed considers the reduction of vehicles within the area of Carles Buigas Avenue by reducing the amount of circulation directions and expanding the exclusive scope or priority for pedestrians. The pedestrian zoning of Carles Buigas Avenue, will convert it into the hub of a network where pedestrians have priority and where the streets perpendicular to this Avenue recognize its new condition and become restricted access streets.

Vehicle access will only be possible to load and unload goods within a restricted time schedule and to provide access to car parks and hotels. Mobility will be complemented by public transport: bicycles and electric buses, which together with improved accessibility and urban space for pedestrians will ensure pleasant journeys and a reduction in time.

2. The reorganisation of the traffic hierarchy, the circulation hierarchy and the defining of the streets for pedestrian use only leads us onto the necessary rethinking of the parking system in the area. It is understood that actual parking needs are of diverse natures. 


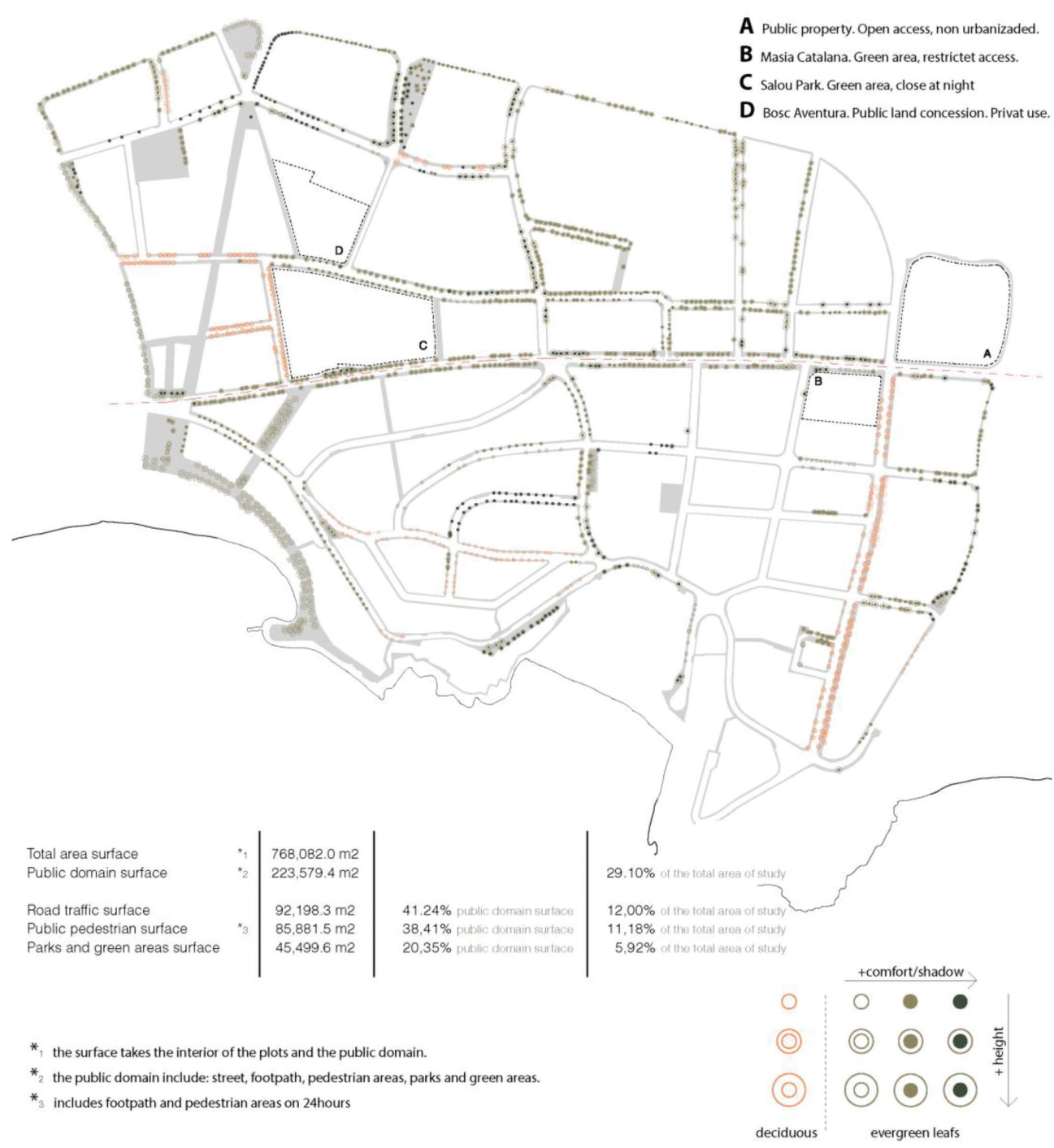

Figure 7: Trees and shadows.

1. Those of the residents, who can count on having or not a private parking space in the buildings in which they reside.

2. Those of the visitors of short or long term duration who stay in holiday homes and apartments, who can count on having or not a private parking space in the buildings in which they reside.

3. Those of the visitors of short and medium term duration who stay in hotels and can count on parking in those places.

4. Those of day visitors who expect to find parking in the area related to the nature of the activities available (beach/restaurants/nightlife) in a defined time zone of a different duration but never lasting more than 24 hours. 
5. Those of occasional day visitors with the desire or need to do something of short duration in the area.

It is a question of parking needs which at present are indiscriminately covered given the existing parking spaces in the public area. This surface area available for car-parks in the street causes the alternative public or private parking, such as that offered by hotels, with a ratio of five rooms per car, to be ineffective.

The road-system reorganization proposed implies gaining public space in the area for pedestrians, by removing car-parks from a significant part of the public space and organizing a system of parking spaces in such a manner as to take into account the different needs of the users. It proposes to integrate a part of the parking spaces in the accommodation facilities, which should have a specific and integrated management system, and study the relocation of the remaining parking spaces in parking lots located in the outskirts of the area or in other parts of Salou.

\subsection{Public space limit versus open private space}

The detailed study of the access to hotels, together with the creation of service roads should resolve the topographical discontinuities between the street and the interior of the plot of land, fomenting a good relationship between the two and providing more permeability between public and private space, but we must also ensure that public parks and gardens do not generate a barrier with their own streets.

From a thorough analysis of the hotels, one can determine that the majority of the hotels in the area have a type of programme layout on the ground floor comprising: an entrance hall, reception and a vertical communications core, lounge or living area of the hotel, service area, bar-restaurant and other client services. Swimming-pools and recreational areas are located in the open outdoor space.

The proposal suggests the greater nexus that some of the services included in the hotels, such as bar, restaurant, boutique, gym or spa, could have in connection with the public space thus providing a new relationship between the hotel and the city (Fig 8).

These proposals may have different degrees of intervention, involving more or less investment and a greater or lesser implication of the public sector. According to this implication three levels of intervention are proposed, taking into account that each one of them will implicate the latter:

1. Internal restructuring of the programme of services for the public within the hotel's own surroundings.

2. Redistribution and organisation of the outdoor areas of the hotel and their relationship with the street.

3. Interchange of building development potential and management of the floors below ground level.

\subsection{Quality of public space}

The preservation of the vegetation mass of the hotel and residential plots of land as well as the public space should be guaranteed. It is imperative to rethink and increase the quantity of trees in the pacified and re-urbanized streets as we have found many streets where trees are 


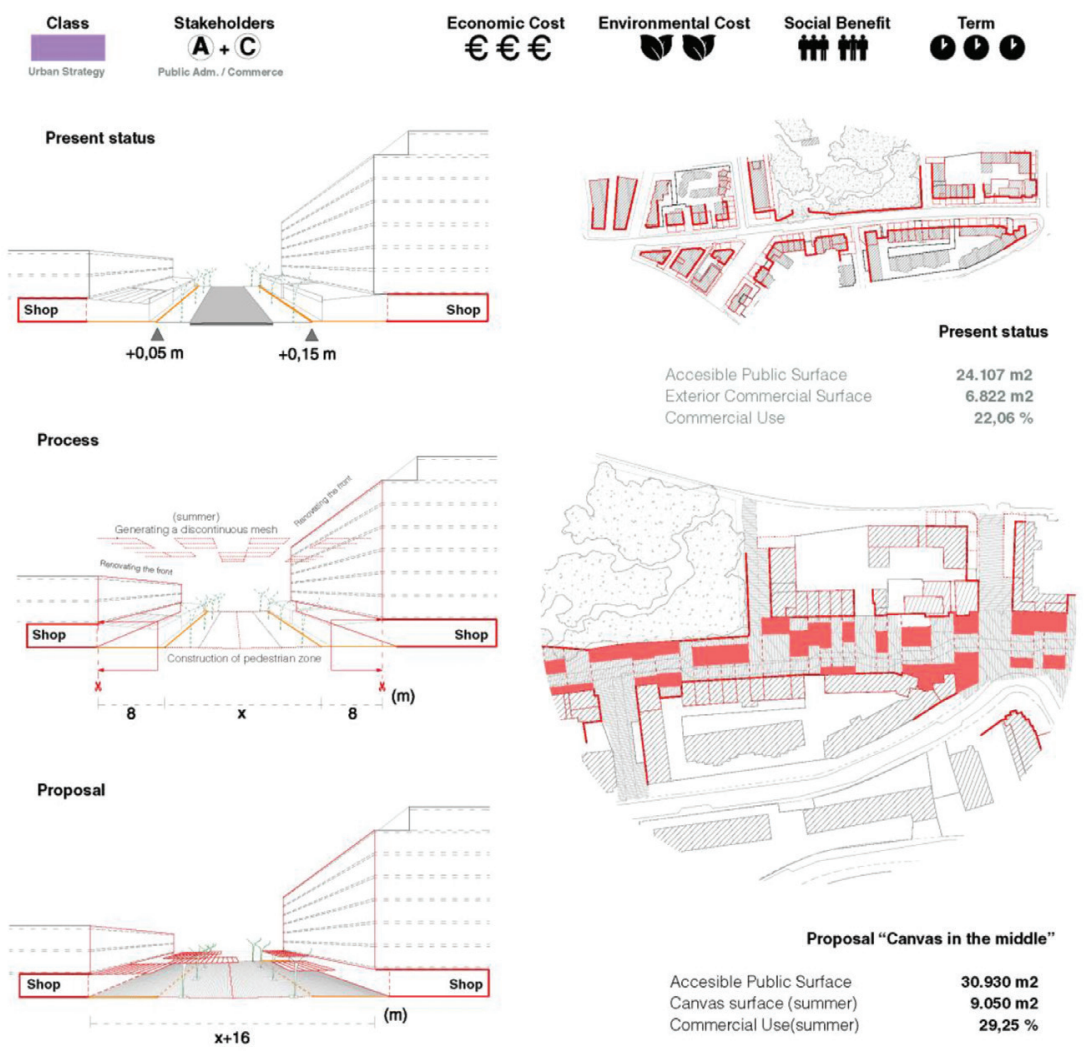

Figure 8: Construction of pedestrian zone in Carles Buigas.

none existent. A good selection of the type of trees in the streets will ensure the areas of shade, providing an increase of freshness and therefore comfort for pedestrians.

Carles Buigas is an urban sector with little vegetation, very urbanized and not very permeable, with a very high cut off surface. To increase the vegetation four levels of action are proposed:

1. In terms of hotel and private open space, measures (regulations) will be necessary to maintain the transpiration of the land, avoiding paving to the extent possible and promoting the introduction of native species of vegetation that help improve the quality of the air.

2. The creation of new areas of vegetation and new inland "corridors" of biodiversity. This action would be linked to the reduction of vehicle mobility and would create streets with a strong presence of vegetation and pavement transpiration.

3. According to new EU directives on public space, having high rates of enclosed urban areas is a serious factor which should be mitigated [12]. This district has areas that clearly exceed this percentage. There are constructive solutions that improve pavement transpiration, termed SUDS (Sustainable Urban Drainage Systems).

4. In terms of landscaping, one could consider planting vegetation on roofs that have a strong public presence, or that could be visible from the hotels. This intervention could 
take place on the roofs of one-level-high commercial premises or the roof of the apartment building of the Capellans beach which has a serious impact on the street.

\section{CONCLUSIONS}

Despite the proposals presented for Salou have similitudes with similar cases implemented in Spain: Playa de Palma (Mallorca), Costa del Sol Occidental (Andalucia), San Bartolomé de Tirajana (Gran Canaria) and Puerto de la Cruz (Tenerife) [13], the strategy differs on the innovation, focus on the methodology rather than in the final proposal. It does not aim the development of every particular proposal, which could delay the beginning of the project, but the boot of the process through small and low budget interventions to test their capacity to shift none desired urban trends at the same time that work as a catalyser to transform the area.

Likewise, the project attempts to involve public and private stakeholders in the funding of the project. While in touristic areas under process of decay the working as usual process of doing was to financially support the regeneration with public funds [13], the context set after the 2008 financial crisis has required the reorganization of previous models. Public financial capacity, especially from municipal administrations, falls diminishing the administrative capacity to impact in urban regeneration through assuming the implied costs. In consequence, innovative solutions are required to overcome the blocking situation.

First, contrary to similar urban regeneration programs with many levels of the administration involved that make the plan inoperative, the Salou urban strategy aims to work bottom-up. There is an absence of other administrations further than the municipality in the managing process. This is reducing bureaucracy, the scale of the plan and the risk of the excessive control from higher levels of governance within the administration [14]. The excessive aspiration of other related plans has driven to the failure of the development by an enormous scale that makes the process inoperative (Palma de Mallorca) and its magnanimous associated costs, also excessively supported on the public administrations (Puerto de la Cruz) [13].

Second, contrary to common regeneration programs, this plan aims to be compressive by the number of sectors involve in the analysis of the study and the development of the proposals [15]. Moreover, public participation is considered key to guarantee the success of the urban regeneration process [15]. Thus, further from previous meeting with the identified main stakeholders in the area: administration and hotels managers, workshops with neighbours, retailers, tourist operators, etc. are being programmed for the summer of 2016, previous to the development of any specific proposal for development.

Third, taking advantage of the location in the area of 28 of the 52 the hotels in the municipality, hotel investors were identified as key stakeholders for the development of the urban strategy. Hotel investors are particularly interested in improving urban conditions in the area, pushed by economic and personal reasons ${ }^{1}$. Moreover, since the tourism market has succeeded in overcoming the crisis period after 2008, hotel companies have today the financial capacity to act. Likewise, their relative small number of representatives (less than the total number of hotels, concentrated in few big hotel groups), contribute to make approval and support of the strategies easier and faster, reducing too extensive times of similar plans [13].

Thus, this initiative aims to, in one hand promote (local) administrative leadership and in the other hand involve private sector with specific and relevant roles to guarantee the success of the process [16]. The plan sets enhance low cost initiatives developed and funded by the local administration to improve public areas, at the same time that, costly developments like

1 The most relevant hotel managers in the area are local families with strong roots in the territory. 
hotel infrastructure renovations are supported by the private sector, despite coordinated and shared under a public-private vision.

\section{REFERENCES}

[1] Hosbec, D. d. E., HOSBEC Monitor. Informe de coyuntura turística Benidorm Costa Blanca Comunidad Valenciana, 2015. (Fuente: HOSBEC, INE y elaboración propia; HOSBEC 1er Semenstre 2015), available at: http://docplayer.es/1810787-Hosbecmonitor-informe-de-coyuntura-turisticabenidorm-costa-blanca-comunidad-valenciana. html (accessed 11 December 2015).

[2] Delgado, X., Xarxa arterial del Camp de Tarragona, Barcelona: Universitat Politècnica de Catalunya (UPC), 2004.

[3] Sabban, M., Report on sustainable tourism in the Mediterranean. (Assembly of European Regions; Ile-deFrance Regional Council/FR. 4th Meeting of ARLEM's Commission for sustainable development (SUDEV) on 16 January 2013 and adopted during the 4th ARLEM plenary session on 18 February 2013 in Brussels, Belgium, 2012, available at: http://cor.europa.eu/en/activities/arlem/activities/meetings/Documents/sudevreport2012-tourism-en.pdf (accessed 15 December 2015).

[4] Anton Clavé, S., Diferenciació i reestructuració de l'espai turístic : processos i tendències al litoral de Tarragona. Tarragona: El Mèdol, 1997.

[5] Salvadó, N., De-Rivera, I., Salvadó, T. \& Lorenzo, D., A declining coastal tourist resort model analysis. The case of Avinguda Carles Buigas in Salou, Costa Dorada. Opportunities for regeneration. WIT. Transactions on Built Environment, 148, WIT Press, 2015, ISSN 1743-3509.

[6] Observatorio del FEDECT, Fundación de Estudios Turísticos de la Costa Dorada, available at: http://www.pct-turisme.cat/, 2014.

[7] Ajuntament de Salou, Àrea de Promoció Econòmica. Dades socioeconòmiques del municipi de Salou, 2012.

[8] IDESCAT, Institut d'Estadística de Catalunya, available at: http://www.idescat.cat, 2014.

[9] Salvadó, N., De-Rivera, I., Salvadó, T. \& Lorenzo, D., L'avinguda de Carles Buigas de Salou: estratègies de regeneració urbana. Primer document, anàlisi de l'estat actual rum[lab], grup de recerca arquitectura, territorio i paisatge, Unitat predepartamental d'arquitectura, Escola d'arquitectura de Reus, 2014.

[10] Venturi, R., Izenour, S., \& Scott Brown, D., Learning from Las Vegas - Revised Edition: The Forgotten Symbolism of Architectural Form Paperback, 1977.

[11] Jacobs, J., The Death and Life of Great American Cities, Random House: New York, 1961.

[12] European Commission., Directorate-General for the Environment., 2012. Guidelines on best practice to limit, mitigate or compensate soil sealing. Luxembourg: Publications Office, (accessed 29 December 2015).

[13] Rodríguez, I. \& Such, M.-P., La política turística española de apoyo a la renovación y reestructuración de destinos turísticos maduros: una valoración a partir de las experiencias piloto recientes [en línea] Fecha de consulta: dd-mm-aa. En: ACE: Architecture, City and Environment = Arquitectura, Ciudad y Entorno, 9(25), pp. 437-466, 2014. http://dx.doi.org/10.5821/ace.9.25.3635

[14] Simancas, M., de Souza, A. \& Núñez, M., La renovación de los espacios públicos de las áreas turísticas consolidadas. In Destinos turísticos maduros ante el cambio. 
Reflexiones desde Canarias, eds : R. Hernàndez \& A. Santana, Instituto Universitario de Ciencias Políticas y Sociales de la Universidad de La Laguna: Producciones Gráficas S.L. pp. 183-216.

[15] Alterman, R., A comparative view of neighborhood regeneration programs in nine countries: are the lessons transferable? Urban Affairs Review (Formerly Urban Affairs Quarterly), 30(5), pp. 749-765, 1995.

http://dx.doi.org/10.1177/107808749503000514

[16] Simancas, M. \& Moises, R., La renovación edificatoria de la oferta turística de alojamiento en destinos consolidados: La experiencia de Canarias. Cuadernos De Geografia, 87, pp. 23-44. 